\title{
Deconstructing the diaspora: The construction of Chinese-Indonesian identity in post-
}

\section{Suharto Indonesia}

One of the most telling aspects of the polemics surrounding the issue of Chinese identity in Indonesia is the very language in which it is embedded. The Chinese, their culture, their religion, arguably their very existence in Indonesia, have been branded by colonialists, scholars and politicians alike as masalah Cina, 'the Chinese problem.' I am not necessarily suggesting that this has become a self-fulfilling prophesy, but I would argue that we are shaped, influenced, and to a certain extent defined by the labels that others put on us. In the case of the Chinese in Indonesia, it certainly seems to be a case of 'once a masalah, always a masalah.' Or, to look at it another way, as Ignatius Wibowo recently asked—rhetorically, presumably—: 'At what point does a person's Chinese-ness cease to be?') ${ }^{1}$ As I will demonstrate later in this chapter, labelling has played a very significant part in the way in which Chinese-Indonesians view and understand themselves and are viewed and understood by others.

Chinese-Indonesians have occupied an ambivalent and at times turbulent position in Indonesia since the days of Dutch colonialism. Under their divide-and-rule policy, the Dutch colonial government encouraged the Chinese to preserve their own identity, discouraging assimilation. After Indonesia gained independence in 1945, indigenous nationalists who had hitherto been preoccupied with overseeing the end of colonialism, began to turn their attention to the Chinese as 'Other'. The project of Indonesian nation-building thus generated a pribumi (native) versus nonpribumi ethnic tension which has been a constant feature of identity politics in post-colonial Indonesia.

The so-called masalah Cina has been the subject of a number of scholarly works. ${ }^{1}$ The Chinese have been subjected to othering in Indonesia on account of their cultural and religious difference, on account of their dominance in the nation's economy and (paradoxically, as this seems to

1 Sampai kapan ke-cina-an seseorang berhenti? I.Wibowo, 'Kapan ke-Cina-an akan berhenti?' Mitra 4, Maret 2000, p.8. 
contradict that economic dominance) on account of their purported complicity with Communism. Scholarly analysis of issues confronting the Chinese minority in post-colonial Indonesia has focused upon the nexus between ethnicity, nationality and identity and the ways in which the Chinese 'difference' is seen to problematise notions of a coherent nation-building project in Indonesia.

After assuming the Indonesian presidency in 1966, following the attempted putsch (officially constructed an 'abortive Communist coup') which led to the fall of his predecessor Sukarno, President Suharto issued a decree which forbade any activities pertaining to Chinese religion or culture. Chinese schools and organisations were banned. Chinese personal and business names were forbidden. The use of Chinese script was banned, except for the dual-text newspaper Harian Indonesia, which was permitted under strict licence and government scrutiny to publish news in both Indonesian and Mandarin. The aggressive witch-hunt and victimisation of ChineseIndonesians following the attempted 1965 coup, justified on the grounds of their alleged complicity with Communism, transformed itself into an insidious silencing, intimidation and discrediting of Chinese throughout Suharto's New Order regime. The vulnerability of the Chinese in political terms was exploited by New Order officials, who permitted Chinese involvement in business while taking a generous percentage of the profits for themselves.

Unlike the anti-integrationist policy of the Dutch colonial government, the official government response to the masalah Cina in the New Order was an assimilation programme, the Program Pembauran, which was predicated upon the idea that Chinese ethnicity was incompatible with the 'national personality, ${ }^{2}$ and that erasure was therefore the only viable solution. Under this programme intermarriage and conversion to Islam were actively encouraged.

In the early 1990s there were signs of a softening in attitude, at least at the official level, towards Chinese-Indonesians. This coincided with the growth in the Indonesian middle class; a significant number of successful media figures for example were Chinese. A weekly magazine, Sinar, aimed at a Chinese readership (and financially backed by the uncle of President Suharto's wife) appeared on the market in 1993. 
But these tentative signs of change were insignificant by comparison with the dramatic changes wrought upon the lives of Chinese-Indonesians during the upheaval that began in mid-February 1998 and culminated in the resignation of Suharto in May of that year. This four-month period was marked by appalling violence against Chinese and their businesses, and the rape of hundreds of Chinese women. Suharto's resignation then led to a space-clearing, which suddenly provided opportunities for Chinese-Indonesians to openly discuss their experiences as an oppressed minority. This space-clearing was extended on 17 January 2000 when President Wahid officially revoked the presidential decree of 1967. Chinese-Indonesians were thus able to celebrate Chinese New Year openly for the first time in thirty-three years.

\section{Changes in identity issues since 1998}

Political developments in Indonesia subsequent to the dismantling of President Suharto's authoritarian New Order regime have been the focus of great international attention. The dramatic economic and political changes of the last four years have been the subject of much analysis. But an important issue that has not yet been systematically addressed is the impact of this profound social and political change on the way individuals and groups in Indonesia view themselves. One of the New Order's primary concerns had been the development of the 'ideal' Indonesian citizen. With the dismantling of New Order state structures and ideologies, alternative discourses of identity became possible, giving rise to new notions of Indonesian-ness. A significant part of this re-negotiation of the self in Indonesia has been the re-emergence of Chinese consciousness. ${ }^{3}$ After January 2000 a plethora of organisations devoted to Chinese cultural and literary activities sprang up, along with dual-language publications such as Mandarin Pos and Zhuinan Ribao, the first newspaper solely in Mandarin. The violence that was perpetrated against Chinese-Indonesians in 1998 was in part the inspiration for the establishment of a non-profit organisation known as the World Huaren Federation, which developed into an extremely popular on-line discussion forum ${ }^{4}$ for overseas Chinese, including Chinese-Indonesians. The sheer volume of postings in 1998 is testament to the need felt by Chinese-Indonesians for an outlet for their fears and aspirations. The Lembaga Pendidikan Bahasa Tionghoa (Institute for the Teaching of Chinese) in Surabaya now 
has an interactive website dealing not only with Mandarin, but also with various facets of Chinese culture and festivals. Just last month Specify when the Universitas Muhammadiyah in Yogyakarta established both a Centre for the Study of Chinese (language) (Pusat latihan bahasa Tionghoa) and a Centre for the Study of Sinology (Pusat Studi Sinologi). (It was in fact President B.J. Habibie who issued a presidential instruction requiring the authorities to allow the teaching of Chinese, in May 1999.)

Among the numerous political parties that sprang up after the fall of Suharto were a number specifically concerned with issues pertaining to the status of Chinese-Indonesians in the reformasi era. The diverse nature of these political parties reflected the diversity of views among ChineseIndonesians about their appropriate status in late twentieth century Indonesia. Parpindo, Partai Pembauran Indonesia (the Indonesian Assimilationist Party), for example, declared its genesis to be 'a reaction to the failure of the assimilation process under Golkar'.2 Other Chinese-oriented political parties included Partai Reformasi Tionghoa Indonesia (Parti), Persatuan Saudara Baru Indonesia (Persabi) and Partai Bhinneka Tunggal Ika Indonesia (PBI).

But 'freedom' can be something of a double-edged sword. For some, the new opportunities it delivers can be frightening and confusing. And the responses to this freedom among ChineseIndonesians are by no means homogeneous. In particular, three issues generate a diversity of response among Chinese-Indonesians.

The first is the issue of labelling. Along with his 1967 presidential decree, Suharto introduced the term Cina as a replacement for the Indonesian words Tiongkok to refer to China and Tionghoa to refer to Chinese. This was intended to emphasise a link between the Chinese and the Indonesian Communist Party, which had been blamed officially for the attempted coup against Sukarno in 1965. There was a general belief that leftist politics had always been supported by a large portion of Chinese-Indonesians, and because the People's Republic of China was Communist, 'Chinese' was essentialised as being the same as 'Communist'. It is this essentialism which has in part

2 reaksi atas tidak berjalannya proses pembauran yang dijalankan Golkar ('Tidak berjalannya proses asimilasi mendorong pembentukan Parpindo'. Kompas, 9 June 1998. Initial cap? Close bracket? 
triggered and vindicated the targeting and scapegoating of Chinese-Indonesians at times of political and economic crisis in Indonesia. The other element in the equation is the dominant position occupied by the Chinese in the nation's economy. The Chinese have thus acquired a paradoxical status in Indonesia—economically they are perceived as dominant, but politically and culturally they are pariahs. The word Cina thus became a derogatory term. But what should we now be calling Chinese-Indonesians? Amongst Chinese-Indonesians themselves there is considerable diversity of opinion on the topic. The high-profile academic and political commentator Arief Budiman, for example, has declared that it is no longer an issue-Cina has become a value-free word and can be used without fear of giving offence (and indeed Chinese-Indonesians born since 1967 know no other word for 'Chinese'). Others take issue with Arief and maintain that Tionghoa is the only politically-correct term. Some Indonesians even use the English word Chinese because they are confused as to what is currently acceptable. At the official level, just two weeks ago when? President Megawati formally revoked the use of Cina, reinstating Tiongkok and Tionghoa.

Allied with this are debates about the nexus between ethnic and national identity. In 2000, for example, a lecturer in Mandarin at SOAS in London,: replace with footnote with name and personal communication and date? a Chinese-Indonesian from Jakarta now living in London, was adamant that Chinese-Indonesians should forget their Chinese ethnicity in the interests of a harmonious and homogeneous Indonesian nation. She was almost proud that her children speak no Mandarin at all and can't communicate with their grandmother. There are other ChineseIndonesians, some high-profile, such as the film-maker Teguh Karya, for whom ethnicity is simply not an issue. Their Chineseness is irrelevant. This denial or effacement of Chinese ethnicity represents perhaps one end of the spectrum. At the other end is the response of a prominent member of the National Commission on Violence Against Women. When interviewed last year when? about the re-emergence of Chinese consciousness, her response was, 'Oh well, all sorts of people are coming out of the woodwork now and declaring themselves to be Chinese-Indonesian. It's become the trendy thing to do!'

The third issue is the way in which we speak about cultural products of Chinese-Indonesians. Is it still appropriate to use the term Chinese-Indonesian literature, for example, as if it is a type of 
diasporic literature? Wilson Tjandinegara uses the term Inhoa, indicating the two cultural elements in this literature-Indonesia and Tionghoa. When we speak of Indonesian literature, theatre or music, is the 'default setting' literature written by pribumi Indonesians, meaning that we still need to qualify other types of literature with the appropriate epithet? Does the use of the epithet illuminate or otherwise?

\section{Cultural expressions of identity}

Since the early twentieth century Indonesian writers and artists have engaged with the project of creating and defining Indonesian identity. This was a project that developed out of the nationalist movement and the conditions of late colonialism. Literature and art thus became understood as not merely products for consumption and entertainment, but rather as a significant part of the nationalist movement. Most serious writers and artists engaged with the project of interrogating and investigating issues of national identity. In New Order Indonesia various forms of cultural activity—literature, theatre, music, the visual arts—continued to operate as sites of both political resistance and the negotiation of identity. The best-known Indonesian literary works from the late twentieth century-the novels of Pramoedya Ananta Toer and Y.B. Mangunwijaya, the short stories of Seno Gumira Ajidarma, the poetry of Rendra, Putu Oka and Wiji Thukul—along with the plays of Ratna Sarumpaet and Riantiarno and the music of Iwan Fals dan Franky Sahilatua are all the products of socially-engaged writers and artists grappling with issues pertaining to what it means to be 'Indonesian'.

How then, if at all, are Chinese-Indonesian writers and artists voicing issues pertaining to identity and political status through literary, theatrical, musical and other forms of cultural expression in the post-Suharto period, now that they are technically 'free' to declare their Chinese heritage? Like the Chinese-Indonesians themselves, the nature of this cultural production is diverse. Some cultural activities are largely decorative, symbolic and not overtly politically or socially engaged. Some - particularly in the visual arts—are gentle, almost tentative explorations of identity that are poignant rather than confronting. In literature, there are stories that address issues of broad social concern-the exploitation of women, oppressive bosses and the evils of Western 
education - and others that more overtly address issues central to the masalah Cina, in particular the possibility and nature of friendship between Chinese-Indonesians and pribumi Indonesians. And there are some which are unambiguously inspired by the dreadful events of early 1998. To quote the Chinese-Indonesian poet Wilson Tjandinegara, 'The tragedy of May 1998 rocked the world. Most of the victims were of Chinese ethnicity. It was a tragedy that has left a dark stain on the history of Indonesia. A poet who has any compassion must condemn those events and convey his sympathy to the victims through his poetry..."3

The most visible Chinese cultural activity since the fall of Suharto has been the Barongsai, the Chinese Lion Dance, which effectively came to symbolise the freedom of expression now granted the Chinese in Indonesia. After three decades of lying low, 'the dragon was only sleeping, ${ }^{4}$, declared a Kompas article in February 2000. To commemorate Chinese New Year in January which year, the television station RCTI screened the Chinese historical romance film Lo Fen Koei, which was shot in Tangerang and Cirebon during the preceding year. The daily national newspaper Kompas printed a half-page pictorial display of Imlek (New Year) celebrations, as well as a large feature article, as if, to quote the online magazine Mandiri 'to emphasise that your [Chinese citizens'] existence is acknowledged in this chaotic republic of ours. ${ }^{5}$ For its part, Mandiri Online established Imleknet, a column designed to provide information about Chinese New Year and Chinese culture. ${ }^{6}$ The classic Chinese-Malay novel Boenga Roos dari Tjikembang, first published in 1927 (and a favourite of 'housewives' to quote the critics), has also been revived: it was

3 Tragedi bulan Mei, telah menggemparkan dunia. Korbannya kebanyakan dari etnis Tionghoa. Sebuah tragedi yang meninggalkan noda hitam dalam sejarah Indonesia. Sebagai penyair yang punya hati nurani, pasti mengutuk peristiwa tersebut dan menyampaikan simpatinya kepada para korban, dengan caranya seorang penyair. Wilson Tjandinegara, Rumah panggung di kampung halaman, Jakarta: Komunitas Sastra Indonesia, 1999, p.28.

4 Sang Naga hanya tidur Kompas 5 February 2000.

5 Menegaskan bahwa eksistensi Anda diakui di republik yang sedang urakan ini. Mandiri Online January 262001.

6 Ibid. 
reprinted by a Yogyakarta publishing house and performed as a stage play at the time of Chinese New Year in Jakarta which year.

A performance genre with an overt political sentiment is the Chinese puppet performance wayang Po Tay Hie which, like most other Chinese cultural performances, was banned by the New Order government, but has been revived and presented to appreciative audiences. Founded around 3,000 years ago in mainland China, wayang Po Tay Hie is believed to have been brought to Indonesia by Chinese immigrants in the eighteenth and nineteenth centuries. The performances, which are usually in Mandarin or Malay, are based on Chinese mythology and legends, but the themes of power, the weak versus the strong and the subversion of truth lend themselves readily to more contemporary interpretations.

Apart from stories that deal overtly with the events of 1998, the masalah Cina is invoked in recent fiction through gentle and optimistic-idealistic even—stories about the possibility of friendship and understanding between Chinese and pribumi Indonesians, stories in which ChineseIndonesians demonstrate a generosity of spirit towards their pribumi friends. This 1998 picture of Amien Rais, and the caption accompanying it, seems to tap into that optimistic frame of thinking:

The declaration and inauguration of the leaders of the Solo branch of PAN on Sunday 13 November was enlivened by the Barongsai, which has been 'buried' for more than thirty years. Here we see the lion performing in front of national PAN leader Amien Rais, who, prior to the performance had presented the performer with an angpao (red envelope).

(The Huaren Federation, however, more cynically suggested that it could be read as 'a political strategy to buy the Chinese minority.' $)^{7}$

Since 1998 a number of Chinese-Indonesian visual artists have been exploring identity issues through their work. The young installation artist Anna Zuchriana is an example. Anna's mother is of Chinese descent and her father is a Jakarta Malay. Her family is Muslim, but they live in an area adjacent to China Town in Jakarta. By her own admission, before May 1998 Anna's understanding of herself as a Chinese-Indonesian had been almost latent, something she hadn't really noticed, but in the space of a few minutes, when her house was surrounded by an angry mob of youths, she

7 http://www.huaren.org/focus/id/111698-05.html Sighted 30 October 2001. 
suddenly realised that the duality within her was an issue, it did matter, and this was the genesis of a subsequent exhibition titled Kenapa sih Cina?, 'Why the Chinese(-ness\}'? Her art is not simply, or perhaps not at all, a political statement; it is a very personal reflection on the tension and ambivalence that informs her sudden confrontation with her ethnicity. One particularly poignant piece titled 'Which one should be covered?' depicts Chinese women who are not Muslim covering their faces with jilbab to avoid attacks.

Although the terror of the killings, rape and fear of 1998 are made explicit in some recent literary production, especially short stories, there is an understated quality about them, a restraint almost. On the whole these stories are marked by sadness and pathos; rather than defining the narrative, the anger and resentment simmers below the surface. By way of example, (my translations of) two very short recent pieces are presented below. ${ }^{5}$ The first is a 'mini-story' by A. Jiao called Peci, originally written in Mandarin. A peci is the black velvet cap worn by Muslim men in Indonesia:

The wind whipped around our legs. Above us, dark clouds skittered across the sky, threatening to engulf our little town. The combination of ubiquitous dustlegacy of a long dry season - and air pollution made it hard to breathe. I was giving Salman a ride on my Vespa through the shopping precinct. The next night his son was to be circumcised and he'd asked me to take him shopping.

I parked the bike and we strapped our helmets to it, then set off towards the supermarket. Suddenly another clump of dark clouds appeared in the distance and began to approach us. This time it was a mass of people, shouting hysterically as they ran towards us. As they got closer the normal confused rabble of voices in the market began to recede, and people ran off to hide. In an instant the steel shop doors were slammed shut.

'A Siong, let's get out of here!' In the midst of the chaos Salman was pushing me back towards the bike. When I'd got it going, I suddenly felt him behind me, jamming his peci, which he wore every day, onto my head.

The mob swarmed past me, screaming hysterically. I concentrated on keeping control of the bike. I could hear Salman praying behind me. It sounded as if he was reciting verses from the Koran.

Eventually we were clear of the commotion and I picked up speed, glancing back from time to time. Near where I'd parked the bike I could see a number of vehicles in flames. Thick smoke billowed above the supermarket, mingling with the clouds. Yet another tragedy! Once again, I ached inside.

I touched the velvet peci. I was so moved. I'd seen him wearing it every day for the last ten years or more, but I'd never really noticed it. Who would have thought that one day I'd wear that very same peci and that it would save me from disaster.

The second is an excerpt from a short story titled Mawar by Nano Riantiarno. Mawar means rose: 
There was a little girl called Mawar. She was still in primary school. Not long after the tragedy of May 1998 she came home from school and asked her father: 'Dad, what's my name?' Naturally her father was thrown by this question, and he said nothing for a moment or two. Then he said, 'Your name is Mawar.' But the child was insistent, pestering him to tell her what her real name was. Then he realised what was behind her question. It transpired that the girl's friends had been nagging her to tell them her 'original name' which couldn't possibly be 'Mawar'. Her distinctive complexion and her almond-shaped eyes were what had prompted their questioning.

Poets too have invoked 1998 in their recent poetry. Medy Loekito's poem titled simply '14

May 1998' reads

the night has lost its clarity

i reach for God's hand

it isn't there ${ }^{8}$

Wilson Tjandinegara's poem 'We must not remain silent' is a poignant plea for recognition as a human being, infused with an anger that is palpable yet restrained:

Because we've always been patient we've often been the victims

the scapegoats

For that reason we must not remain silent!

There must be a limit to our stoicism

in the face of unfair treatment

and humiliation

Because we must not remain silent!

We are humans too, we are humans!

with the same rights

however downtrodden we may be

malam tak lagi hening / kugapai tangan Tuhan / tiada Mitra 4 March 2000, p.29. 
For that reason we must not remain silent! ${ }^{9}$

Not only is there a broad spectrum of positioning amongst Chinese-Indonesians in respect of their identity, there is also a considerable range of response to this new situation among pribumi Indonesians. The best-known champion of Chinese-Indonesians in Indonesia is Pramoedya Ananta Toer, who has written a book, Hoakiau di Indonesia, about their contribution to the Indonesian nation (a book originally written in the 1960s and banned by Sukarno, then re-released which year?). In the arts, in academia and in business Chinese-Indonesians and pribumi work alongside each other. However, in many quarters the masalah Cina remains couched in the pribumi versus non-pribumi polemics which Ariel Heryanto identifies as a powerful means of othering the Chinese. Heryanto has written compellingly of how the ethnic Other is indispensable for the reproduction of the native Self. It is an issue which is addressed in a novel by a pribumi Indonesian, Putu Wijaya. The novel is called Perang and is a sort of postmodernist rendition of the Bharatayudha war in the Mahabharata epic. In it the ogres, the really evil faction of the story, are clearly intended to represent the Chinese in contemporary Indonesia. The wise clown-servant Semar muses:

The enemy serves many functions. He is a tool for fine-tuning our minds and bodies, so that we are ever-ready, ever-alert and ever-mindful. He trains us to win. $\mathrm{He}$ hones our thoughts so we don't become neglectful, stagnant or careless. We should tend to the enemy in the same way as we tend a garden, so that we are always occupied, so that we don't become tired of waiting. Like a garden, the enemy provides a focus where we can channel our energies during times of recreation.

9 Karena terus bersabar / kita sering jadi korban / jadi kambing hitam

Karenanya, kita tak boleh berdiam diri!

Menerima perlakuan tidak adil / menahan diri terhadap hinaan orang / ternyata ada batasnya

Karena, kita tak boleh berdiam diri!

Kita juga manusia, adalah manusia! / punya hak yang sama / betapa mungkin diinjak-injak

Karenanya, kita tak boleh berdiam diri!

Nanang Surjadi, 'Tragedi Mei 1998 dalam sajak Wilson Tjandinegara', Mitra 4 March 2000, p.48 
Since the fall of Suharto, change and uncertainty remain arguably the only 'constant' in Indonesia. Chinese-Indonesians are experiencing-whether they like it or not—an increased visibility in the cultural sphere, but on the whole it remains decorative and symbolic (and the cynic may argue, pragmatic), rather than truly transformative. As a category, 'Chinese-Indonesian' remains diverse and heterogeneous, as indeed is the 'native Self' against which it is repeatedly pitted. The masalah Cina has not been 'solved'; it is just being re-defined.

\section{BIBLIOGRAPHY}

Aspinall, E., Feith, H. and van Klinken, J. (ed.), The last days of President Suharto. Melbourne: Monash Asia Institute, 1999.

Blusse, Leonard, Strange company: Chinese settlers, Mestizo women, and the Dutch in VOC Batavia. Dordrecht-Holland: Foris Publications, 1986.

Boedhi S., 'Re: Istiqulal (28/8/98) Cina atau Tionghoa?' http://www.minihub.org/mailinglists/siarlist/msg00754.html 1998. Sighted 19 November 2001.

Budiman, A., Hatley, B. and Kingsbury, D., Reformasi: Crisis and change in Indonesia. Clayton: Monash Asia Institute, 1999.

Coppel, Charles A., Indonesian Chinese in crisis. Kuala Lumpur: OUP, 1983.

Fernando M.R. and Bulbeck, David, Chinese economic activity in Netherlands India: Selected translations from the Dutch. Singapore: ISEAS, 1992.

Forrester, Geoff, Post-Suharto Indonesia: Renewal or chaos? Bathurst, NSW: Crawford House Publishing, 1999.

Godley, Michael R. and Lloyd, Grayson J., Perspectives on the Chinese Indonesians. Bathurst, NSW: Crawford House Publishing, 2001.

Herawati, Zoya, Prosesi, jiwa yang terpenjara. Jakarta: Balai Pustaka, 1999. 
Heryanto, Ariel, 'Ethnic identities and erasure: Chinese Indonesians in public culture.' In: Southeast Asian identities: Culture and the politics of representation in Indonesia, Malaysia, Singapore, and Thailand, Kahn, Joel S. (ed.), Singapore: ISEAS, 1998.

Kwee, Tek Hoay, The origins of the modern Chinese movement in Indonesia. Williams, Lea E. (trans. and ed.), Ithaca, N.Y.: Modern Indonesia Project, Southeast Asia Program, Cornell University, 1969.

Loekito, Medy, 'Puisi'. Mitra 4 March 2000, p. 29.

Mackie, J.A.C., The Chinese in Indonesia. Melbourne: Australian Institute of International Affairs, 1976.

Medan, Anton, ‘Balada kambing hitam kerusuhan'. Kompas 1 June 1998.

Surjadi, Nanang, 'Tragedi Mei 1998 dalam sajak Wilson Tjandinegara,' Mitra 4, March 2000, pp. $47-50$.

Suryadinata, Leo, Pribumi Indonesians, the Chinese minority, and China: A study of perceptions and policies. Kuala Lumpur: Heinemann Educational Books (Asia), 1978.

Suryadinata, Leo, Political thinking of the Indonesian Chinese, 1900-1995: A sourcebook.

Singapore: Singapore University Press, 1997a.

Suryadinata, Leo, The culture of the Chinese minority in Indonesia. Singapore: Times Books International, 1997b.

Tjandinegara, Wilson, Kumpulan cerpen mini Yin Hua. Jakarta: Komunitas Sastra Indonesia, 1999a. Rumah panggung di kampung halaman. Jakarta: Komunitas Sastra Indonesia, $1999 \mathrm{~b}$.

Wibowo, I,. 'Kapan ke-Cina-an akan berhenti?' Mitra 4 (Maret) not indicated in similar entries 2000, 7-9, 66-68.

Widiadana, Rita A. 'Chinese puppets perform once more.' Jakarta Post, 5 February 2000.

Wijaya, Putu, Perang. Jakarta: Pustaka Utama Grafiti, 1990.

Willmott, Donald Earl, The national status of the Chinese in Indonesia 1900-1958. Ithaca, N.Y.: Modern Indonesia Project, Southeast Asia Program, Department of Far Eastern Studies, Cornell University, 1961. 
Unattributed articles:

‘Allow teaching of Chinese, Habibie orders.' Straits Times, 8 May 1999.

'Bersatunya etnis Tionghoa seluruh dunia di Internet.' Nurani bangsa 42? August 2000.

'Boenga Roos dari Tjikembang benturan cinta terlarang.' Mandiri Online, 9 March 2001.

‘Cap Go Me hidupkan kembali wayang 'Potehi-Tiongkok'. Mandiri Online, 9 March 2001.

'Cina di tubuh peradaban kita'. Forum Keadilan 20 February 2000.

‘Gong Xi Fat Cai.’ Mandiri Online, 26 January 2001.

'Persabi dukung Presiden soal istilah 'Tiongkok-Tionghoa'. Antara, 17 November 2001 10:27:41

AM. http://www.antara.co.id/berita.asp?id=18599 Sighted 18 November 2001.

'Sign of tolerance for Chinese culture?' Worldwide Huaren Peace Mission http://www.huaren.org/focus/id/111698-05.html 16 November 1998. Sighted 1 November 2001.

‘Tidak berjalannya proses asimilasi mendorong pembentukan Parpindo’. Kompas, 9 June 1998.

'Tiga dasawarsa, sang Naga hanya tidur.' Kompas 5 February 2000.

‘Tionghoa: Dialektika sebuah etnis'. Kompas, 14 March 2001.

‘Wayang Poo Tay Hie, setelah 32 tahun menghilang’. Kompas, 21 October 1999.

1 Willmott 1961, Kwee 1969, Mackie 1976, Suryadinata 1978, 1997, Coppel 1983, Blusse 1986, Fernando and Bulbeck 1992, Heryanto 1998.

2 Heryanto 1998, 103.

3 See for example the special edition of the cultural journal Mitra, 4 March 2000.

4 www.huaren.com

5 My translations. 